\title{
Introduction to concepts and proposed standardization of the term "Quaternary"
}

Secretary-General of IUGS International Commission on Stratigraphy (ICS), Department of Earth \& Atmospheric Sciences, Purdue University, Indiana 47907-2051, USA; E-mail: jogg@ purdue.edu

\section{Tertiary, Neogene, Pleistocene, Holocene and Quaternary-evolution of a confusion}

During the early 1800's, the current Cenozoic Era (Phillips, 1840) underwent competing schemes of subdivision based on field relationships or on biological evolution.

The terms "Tertiary" (Arduino 1760-conceived for Italian deposits that were commonly derived from "Secondary" layered rocks) and "Quaternary" (Desnoyers, 1829-originally referring to marine and alluvial sediments in the Seine Basin) progressively focused on the uppermost portion of the original "Secondary". This trend had even culminated in a suggested "Quinquennaire" (Parandier, 1891) for the most surficial deposits. The "Quaternary" became a very useful but relatively vague term for the field mapping of less consolidated surficial deposits; and most older geological maps do not clarify the age assignments for their "Quaternary" units.

Lyell (1833) subdivided the Tertiary into Eocene, Miocene and Pliocene according to the relative similarity of mollusk species assemblages to present fauna. His youngest unit of Newer Pliocene was later (1839) abbreviated to "Pleistocene". In 1857, Lyell formalized a "Recent" epoch, which was renamed "Holocene" by Gervais (1867). Lyell never adopted the term "Quaternary", but indicated that Desnoyerís concept was approximately equivalent to his Newer Pliocene to Recent epochs of the Tertiary.

After Louis Agassiz (1840) proposed that the "Diluvial" deposits over large parts of Europe and North America originated from massive glacial episodes rather than the Biblical Flood, Forbes (1846) proposed equating the term Pleistocene (or Glacial Epoch) with these deposits.

The terms "Neogen Stufe" and "Paleogen Stufe" were introduced by Hörnes (1853) for subdividing the Cenozoic deposits in the Vienna Basin. The Neogene of Hörnes encompassed fauna of the Miocene, Pliocene and Pleistocene. These two major divisions of the Cenozoic were adopted by the International Commission on Stratigraphy.

Gignoux (1910) proposed a"Calabrian" Stage for the lowermost Pleistocene of Lyell. The type sections for this "Calabrian" stage are approximately equivalent to the present "Middle" Pleistocene (younger than 0.9 Ma).

When the International Commission on Stratigraphy (ICS) and the International Union for Quaternary Research (INQUA) prepared to standardize the Pliocene/Pleistocene boundary, there were three main options on how to formally define and assign a GSSP for the base of the Pleistocene Epoch-(1) Lyell's "Newer Pliocene" (and original concept of Calabrian Stage) version $(\sim 1 \mathrm{Ma})$, (2) a placement near the top of the Olduvai paleomagnetic subchron ( 2 Ma), or (3) near the Gauss/Matuyama reversal ( 2.5 Ma). A draft proposal on the choice of a boundary stratotype for the Pliocene/Pleistocene boundary was submitted and approved by the INQUA Commission on Stratigraphy (also acting as the Subcommission on Quaternary Stratigraphy of the ICS) at the 1982 Moscow INQUA Congress. The decision to assign the GSSP at Vrica in Sicily for the base of the Pleistocene near the top of the Olduvai subchron $(1.8$

Ma) was approved by ICS in 1983 , and this boundary decision was "isolated from other more or less related problems, such as... the status of the Quaternary within the chronostratigraphic scale" (Aguirre and Pasini, 1985). In some respects, the basal-Pleistocene placement was a compromise. The oldest option, the Gauss/Matuyama reversal, was used to define the GSSP for the "Gelasian" stage of uppermost Pliocene, and the youngest option will probably be near the GSSP level for the Middle "sub-epoch" of the Pleistocene.

The "Quaternary" has become traditionally equated with the North Hemisphere glacial episodes. The evidence from marine isotope records and ice-rafted debris in the North Atlantic which indicate that oscillations in continental ice volume became much more pronounced around 2.6 Ma was one factor in a formal reconsideration and vote in 1998 by the commissions on Neogene Stratigraphy (ICS) and Quaternary Stratigraphy (joint ICS/INQUA) to lower the Pliocene/Pleistocene boundary to the base of the Gelasian Stage. The majority decided to retain the Vrica GSSP. Therefore, if one defines the Quaternary by major oscillations in Northern Hemisphere ice volume, then it begins approximately 0.6 myr prior to the base of the Pleistocene epoch (shown as "A" in Figure 1).

(A) current span of "Quaternary" ( ice volume; but lacks formal definition)

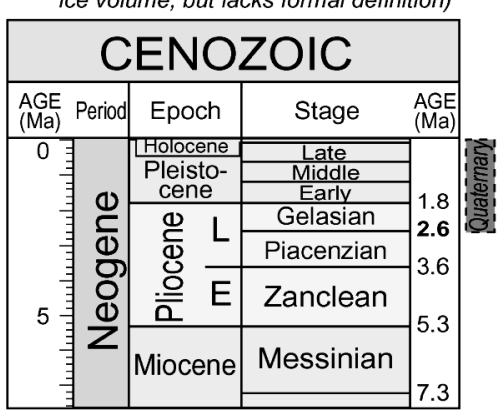

(C) Quaternary is a "composite epoch" (no formal rank in chronostratigraphic scale, but formally defined as Gelasian (2.6 Ma) to Present)

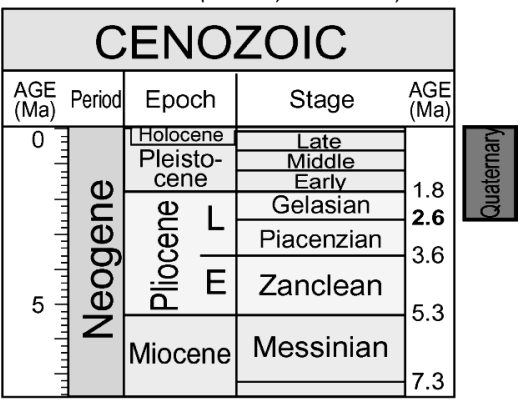

Figure 1 Current status and some possible options for formalizing the "Quaternary" interval of Earth history. Durations of stages, epochs and "Quaternary" on the geologic time scale are according to their span in millions of years. The Neogene Period begins at 23 Ma. 


\section{Some options for formalization of "Quaternary"}

The subdivision of the Cenozoic Era into sub-equal Paleogene and Neogene periods (42 myr and 23 myr long, respectively) would render obsolete the alternative subdivision into a very long "Tertiary" Period (63 myr, or $>95 \%$ of Cenozoic) and a very short "Quaternary" Period ( $<5 \%$ of Cenozoic). The decision to abandon the "Tertiary" follows the historical trend that abandoned "Primary" and "Secondary"; and only a few individuals (mainly involved in field mapping) have expressed a regret at its demise. The comments that "Tertiary" should be retained mainly concern problems in distinguishing between Paleocene and Neogene in non-fossiliferous continental deposits ("Tertiary" is nicely ambiguous by including both) and the dramatic phonetics when saying "K/T boundary" instead of spitting out "K/P boundary".

The "Quaternary", however, remains a very useful climaticbased chronostratigraphic term because it has been equated to the time interval characterized by North Hemisphere glacial/interglacial cycles. At about 2.6 Ma, the Earth system changed from moderate obliquity-dominated climate cycles to the major precession-eccentricity-dominated glacial episodes, and this is the proposed defining criteria for the onset of the "Quaternary".

Brad Pillans, the current chair of the INQUA Stratigraphy \& Chronology Commission, has proposed retaining "Quaternary" as a formal international subdivision of the Neogene Period. He has proposed that the "Quaternary" time interval have the rank of "subperiod" (="sub-system" for the chronostratigraphic rock record) (option "B" in Figure 1, and related item in Forum section of Episodes, this issue). In the current International Geologic Scale, only the Carboniferous Period has formal "sub-systems" (the Pennsylvanian and Mississippian units, which originated as "sub-systems" as a compromise after many years of debate). The "sub-system" Quaternary option is shown in the attached graphic.

There are only some minor obvious concerns with this "subsystem" proposal. First, the base of the Quaternary would not correspond to the base of an Epoch-level division. Of course, the 1998 vote to lower the Pleistocene Epoch boundary was precisely to avoid this problem and allow the "Quaternary" concept to exactly coincide, but the Pleistocene redefinition was not approved. It has been a general (but not stipulated) rule of the formal chronostratigraphic hierarchy that the base of a higher rank always coincides with the base of a lower rank (e.g., the base of the Cenozoic Era must also be the bases of the Paleogene Period and the Danian Stage). Second, the separation of the youngest $2.6 \mathrm{myr}$ of the Neogene Period into a "Quaternary sub-period" would leave a lingering question of whether the preceding 22 myr should also be given a unique "subperiod" name. Third-mainly from an aesthetic viewpoint-the squeezing of a "Quaternary" block between the period-column and the epoch-column makes the time-scale graphics look rather awkward, although this has been done for the Pennsylvanian and Mississippian sub-periods in the Carboniferous.

An alternative would be to formally define the Quaternary as a "composite epoch" (equal to the Holocene and Pleistocene epochs plus the Gelasian stage of the Pliocene; or simply the geologic time interval "younger than 2.6 Ma"), and to indicate its age span and climatic-association on all International Stratigraphic charts (see the suggested graphic) (option "C" in Figure 1). This "composite epoch" would have no formal placement in the hierarchy of chronostratigraphic units. The "Precambrian" is a related concept - a "composite eon" without a formal hierarchal rank on the time scale, but clearly defined ("older than the Cambrian GSSP") and utilized by most international geologists.

Yet another option is that the Quaternary be formalized as a period/system above the Neogene (option "D" in Figure 1), as it has been shown on some geologic time scale charts and equated with the combined Pleistocene and Holocene (e.g., Haq et al., 1988; Remane et al., 2000). However, this would require that its component epochs and stages not overlap the next lower period. Therefore, the Quaternary period would span only the Pleistocene and Holocene, and would no longer encompass the earlier episodes of major North Hemisphere glaciation.

Resolving the definition and official chronostratigraphic status of the Quaternary will be a joint decision by INQUA, ICS, IUGS, and associated organizations.

\section{Acknowledgments}

The historical review is largely condensed from "The Pleistocene and Holocene Epochs" by Gibbard \& van Kolfschoten, the "The Neogene Period" by Lourens et al. and "The Paleogene Period" by Luterbacher et al. (chapters in A Geologic Time Scale 2004, Gradstein, Ogg, Smith, et al., 2004). Brad Pillans (INQUA), Felix Gradstein (Chair of ICS), Steve Walsh and Gabi Ogg provided corrections and additional comments. The views expressed are not meant to represent the majority opinions of either ICS-IUGS or INQUA, but are to encourage discussion and feedback (see associated proposal by Brad Pillans, this issue).

\section{References}

Agazziz, L., 1840, Etudes sur les glaciers, (private edition), Neuchâtel.

Aguirre, E., and Pasini, G., 1985, The Pliocene-Pleistocene boundary. Episodes, 8: 116-120.

Arduino, G., 1760, A letter to Sig. Cav. Antonio Valisnieri. in Nuova raccolta di opuscoli scientifici e filologici del padre abate Angiolo Calogierà (Venice), 6: 142-143

Desnoyers, J., 1829, Observations sur un ensamble de dépôts marins plus récents que les terrains tertiaries du bassin de la Seine, et constituant une formation géologique distincte: précédées d'une aperçu de la non-simulanéité des bassins tertiares. Annales Sciences Naturelles, Paris, 16: 171$214,402-491$.

Forbes, E., 1846, On the connection between the distribution of the existing fauna and flora of the British Isles, and the geological changes which have affected their area, especially during the epoch of the Northern Drift. Great Britain Geological Survey Memoir, 1: 336-342.

Gervais, P., 1867-9, Zoologie et paleontology générales. Nouvelles recherches sur les animaux vertétebrés et fossiles, Paris, 263pp.

Gignoux, M., 1910, Sur la classification du Pliocène et du Quaternaire dans 1"Italie du Sud. Comptes rendus de l'Academie des Sciences, Paris, 150: 841-844.

Gradstein, F. M., Ogg, J. G., and Smith, A. G. (coordinators), Agterberg, F. P., Bleeker, W., Cooper, R. A., Davydov, V., Gibbard, P., Hinnov, L. A., House, M.R., Lourens, L., Luterbacher, H-P., McArthur, J., Melchin, M. J., Robb, L. J., Shergold, J., Villeneuve, M., Wardlaw, B. R., Ali, J., Brinkhuis, H., Hilgen, F. J., Hooker, J., Howarth, R. J., Knoll, A. H., Laskar, J., Monechi, S., Powell, J., Plumb, K. A., Raffi, I., Röhl, U., Sanfilippo, A., Schmitz, B., Shackleton, N. J., Shields, G. A., Strauss, H., Van Dam, J., Veizer, J., van Kolfschoten, Th., and Wilson, D., 2004 (scheduled release is Aug, 2004). Geologic Time Scale 2004. Cambridge University Press, 500 pages.

Haq, B. U., Hardenbol, J., and Vail, P. R., 1988, Mesozoic and Cenozoic chronostratigraphy and cycles of sea-level change. in Sea-Level Changes: An Integrated Approach (edited by Wilgus, C. K., Hastings, B. S., Ross, C. A., Posamentier, H. W., Van Wagoner, J., and Kendall, G. St. C.,), SEPM Special Publication 42: 71-108.

Hörnes, M., 1853, Mitteilung an Prof. Bronn gerichtet: Wien, 3. Okt., 1853. Neues Jahrb. Mineral. Geol. Geogn. Petrefaktenkd., pp. 806-810.

Lyell, C., 1833, Principles of Geology : being an inquiry how far the former changes of the earth's surface are referable to causes now in operation. Volume III. London: John Murray, 398 pp.

Lyell, C., 1857, Supplement to the fifth edition: London, John Murray, 40 pp.

Parandier, H., 1891, Notice géologique et paléontologique sur la nature des terrains traverses par le chemin de fer entre Dijon at Ch,lons-sur-Saône. Bulletin de la Société géologique de France, series 3, 19, 794-818.

Philliips, J., 1840, Palaeozoic series. in The Penny Cyclopaedia of the Society for the Diffusion of Useful Knowledge (edited by G. Long, published by Charles Knight, London), 17: 153-154.

Remane, J. (compiler), 2000, International Stratigraphic Chart, with Explanatory Note. UNESCO/IUGS, Doc. 31st International Geological Congress, Rio de Janeiro 2000: 16 pp. 